University of Nebraska - Lincoln

DigitalCommons@University of Nebraska - Lincoln

$4-12-2008$

\title{
Using Heat to Characterize Streambed Water Flux Variability in Four Stream Reaches
}

Hedeff Essaid

USGS

Celia M. Zamora

USGS

Kathleen A. McCarthy

USGS

Jason R. Vogel

USGS, jason.vogel@ou.edu

John T. Wilson

USGS

Follow this and additional works at: https://digitalcommons.unl.edu/usgsstaffpub

Part of the Earth Sciences Commons

Essaid, Hedeff; Zamora, Celia M.; McCarthy, Kathleen A.; Vogel, Jason R.; and Wilson, John T., "Using Heat to Characterize Streambed Water Flux Variability in Four Stream Reaches" (2008). USGS Staff -- Published Research. 5.

https://digitalcommons.unl.edu/usgsstaffpub/5

This Article is brought to you for free and open access by the US Geological Survey at DigitalCommons@University of Nebraska - Lincoln. It has been accepted for inclusion in USGS Staff -- Published Research by an authorized administrator of DigitalCommons@University of Nebraska - Lincoln. 


\title{
Using Heat to Characterize Streambed Water Flux Variability in Four Stream Reaches
}

\author{
Hedeff I. Essaid, * Celia M. Zamora, Kathleen A. McCarthy, Jason R. Vogel, and John T. Wilson USGS
}

Estimates of streambed water flux are needed for the interpretation of streambed chemistry and reactions. Continuous temperature and head monitoring in stream reaches within four agricultural watersheds (Leary Weber Ditch, IN; Maple Creek, NE; DR2 Drain, WA; and Merced River, CA) allowed heat to be used as a tracer to study the temporal and spatial variability of fluxes through the streambed. Synoptic methods (seepage meter and differential discharge measurements) were compared with estimates obtained by using heat as a tracer. Water flux was estimated by modeling one-dimensional vertical flow of water and heat using the model VS2DH. Flux was influenced by physical heterogeneity of the stream channel and temporal variability in stream and ground-water levels. During most of the study period (April-December 2004), flux was upward through the streambeds. At the IN, NE, and CA sites, highstage events resulted in rapid reversal of flow direction inducing short-term surface-water flow into the streambed. During late summer at the IN site, regional ground-water levels dropped, leading to surface-water loss to ground water that resulted in drying of the ditch. Synoptic measurements of flux generally supported the model flux estimates. Water flow through the streambed was roughly an order of magnitude larger in the humid basins (IN and NE) than in the arid basins (WA and CA). Downward flux, in response to sudden high streamflows, and seasonal variability in flux was most pronounced in the humid basins and in high conductivity zones in the streambed.

Copyright $\odot 2008$ by the American Society of Agronomy, Crop Science Society of America, and Soil Science Society of America. All rights reserved. No part of this periodical may be reproduced or transmitted in any form or by any means, electronic or mechanical, including photocopying, recording, or any information storage and retrieval system, without permission in writing from the publisher.

Published in J. Environ. Qual. 37:1010-1023 (2008).

doi:10.2134/jeq2006.0448

Received 11 Oct. 2006.

*Corresponding author (hiessaid@usgs.gov).

(c) ASA, CSSA, SSSA

677 S. Segoe Rd., Madison, WI 53711 USA
$\mathrm{T}$ HE Agricultural Chemicals Sources, Transport, and Fate Topical Study of the U.S. Geological Survey's National Water-Quality Assessment Program has undertaken a nationwide study to assess the environmental fate of agricultural contaminants (Capel et al., 2004). The goal of the study is to determine the transport and fate agricultural chemicals through the hydrologic compartments from the land surface to the stream as affected by natural factors and agricultural practices (Capel et al., 2008). Understanding the transport of chemicals requires estimates of water flux; understanding the fate of chemicals requires estimates of residence times and reaction rates. As part of this effort, ground-water/surfacewater $(\mathrm{GW} / \mathrm{SW})$ interactions were studied in the streambeds of four watersheds, demonstrating a range of agricultural and hydrologic conditions, to examine the direction and rate of movement of water through the streambed over an extended period (Table 1). The results of this analysis are used by Puckett et al. (2008) to aid in the interpretation of streambed chemistry and nitrate removal.

For the purposes of this study, streambed water flux is defined as the flow rate of water through the streambed per unit streambed surface area $\left(\mathrm{m}^{3} \mathrm{~m}^{-2} \mathrm{~s}^{-1}\right)$ and has a positive value for ground-water flow to surface water and a negative value for surface-water flow to ground water (Stauffer, 2006). Direct measurement of streambed seepage rates, estimates of seepage rates based on changes in discharge along the stream reach, and analysis of streambed heads and temperatures were used to determine the GW/SW exchange rates.

Streambeds can be highly reactive zones, contributing substantially to the attenuation of concentrations of agricultural chemicals (Duff and Triska, 1990; Bradley et al., 1995; Puckett and Hughes, 2005; Tesoriero et al., 2005). In addition, this interface between surface water and ground water can have complex, spatially, and temporally varying flow patterns. The residence time of water in the streambed and the potential for agricultural chemicals to react with streambed sediments is inversely proportional to the rate at which the water moves through the bed. Thus, understanding agricultural-chemical attenuation processes requires quantifying the streambed water flux.

Detailed studies of the spatial variability of streambed water flux within selected stream reaches have recently become available (Conant, 2004; Craig, 2006). Seasonal variability of streambed fluxes has been studied by Fryar et al. (2000) and Gorman (2004). Fryar et al. (2000) confirmed that the distribution of GW/SW flux influenced

H.I. Essaid, USGS, 345 Middlefield Rd., Menlo Park, CA 94025; C.M. Zamora, USGS, 6000 J Street, Sacramento, CA 95819; K.A. McCarthy, USGS, 10615 Cherry Blossom Drive, Portland, OR 97216; J.R. Vogel, USGS, 5231 S. 19th Street, Lincoln, NE 68512; J.T. Wilson, USGS, 5957 Lakeside Boulevard, Indianapolis, IN 46278.

Abbreviations: GW/SW, ground-water/surface-water; ID, inner diameter; K, hydraulic conductivity; PVC, polyvinyl chloride. 
the fate of contaminant plumes and showed that flux rates varied seasonally. Gorman (2004) showed that changing hydraulic properties of the streambed, due to changing river conditions, caused temporal variability in streambed flux. Examination of continuous temporal variability of streambed flux over time scales of months to a year has not been well documented because temperature observation periods have generally been limited to days or weeks, and heads in the streambed have not been monitored continuously (e.g., Bartolino and Niswonger, 1999; Alexander and Caissie, 2003; Ruehl et al., 2006). In this study, we examined the temporal and spatial variability of streambed water flux in four stream reaches within agricultural watersheds from April through December 2004. The detailed characteristics of the watersheds and instrumentation locations are given in Capel et al. (2008).

\section{Leary Weber Ditch, Indiana}

Leary Weber Ditch is a small, intermittent stream draining a $7.2-\mathrm{km}^{2}$ subwatershed within the Sugar Creek Basin in Indiana. This is an intensively farmed corn and soybean region with poorly permeable surface and subsurface materials. It is predominantly loam till with interbedded lenses of sand and gravel (Gray, 1989). Flow in the Leary Weber Ditch is primarily tile-drain fed and responds to snow melt and rainfall events, with flow falling off quickly after an event. Annual mean flow in the ditch was $0.08 \mathrm{~m}^{3} \mathrm{~s}^{-1}$ for calendar year 2004, with $103 \mathrm{~d}$ of zero flow during the relatively dry months of July through November when the groundwater table dropped below the streambed. This area exhibits moderate temperatures ranging from an average of $24^{\circ} \mathrm{C}$ in July to $-4^{\circ} \mathrm{C}$ in January (Lathrop, 2006). The mean annual precipitation is about $1000 \mathrm{~mm}$, with most of the rainfall occurring in spring and early summer. The GW/SW interaction study site on Leary Weber Ditch is $110 \mathrm{~m}$ upstream from the confluence with Sugar Creek in a zone where there is no tile-drain input to the ditch. A small area of outwash deposits borders Sugar Creek near the confluence with Leary Weber Ditch (Gray, 1989).

\section{Maple Creek, Nebraska}

Estimates of streambed flux were made near the mouth of Maple Creek, a $956-\mathrm{km}^{2}$ watershed in eastern Nebraska. This is a glaciated watershed with loess, till, and alluvium at the surface (Fredrick et al., 2006). Till is the predominant material in the upland areas of the watershed but is absent or present only as thin lenses in the lower Maple Creek valley. Surficial deposits in the lower part of the valley are predominantly alluvium near and within the stream and alluvium with a loess cap away from the stream. The climate of the area is characterized by hot summers and cold winters. Total annual precipitation in 2004 was $721 \mathrm{~mm}$, with the highest amounts in May and June. The main channel of Maple Creek intercepted the water table and was perennial, with an average flow of $2.0 \mathrm{~m}^{3} \mathrm{~s}^{-1}$ in 2004 . The GW/ SW interaction study site was about $10 \mathrm{~km}$ upstream from the confluence with the Elkhorn River.
Table 1. Summary of watershed information used for analysis.

\begin{tabular}{|c|c|c|c|c|}
\hline tershed & Area & $\begin{array}{c}\text { Period } \\
\text { monitored }\end{array}$ & $\begin{array}{c}\text { Number of sites } \\
\text { monitored } \\
\text { and analyzed }\end{array}$ & $\begin{array}{c}\text { Flux } \\
\text { estimation } \\
\text { methods used }\end{array}$ \\
\hline & $\mathrm{km}^{2}$ & & & \\
\hline $\begin{array}{l}\text { ry Weber } \\
\text { itch, IN }\end{array}$ & 7.2 & March-Dec. 04 & $\begin{array}{l}\text { two locations, } \\
\text { same transect }\end{array}$ & heat as a tracer \\
\hline & & & & $\begin{array}{l}\text { seepage meter } \\
\text { discharge }\end{array}$ \\
\hline ple Creek, NE & 956 & March-Nov. 04 & one location & $\begin{array}{l}\text { heat as a tracer } \\
\text { seepage meter } \\
\text { discharge }\end{array}$ \\
\hline 2 Drain, WA & 5.5 & July 04- Dec. 04 & $\begin{array}{l}\text { two locations on } \\
\text { different transects }\end{array}$ & heat as a tracer \\
\hline rced River, CA & $\begin{array}{c}822 \\
\text { (lower basin) }\end{array}$ & March-Dec. 04 & one location & $\begin{array}{l}\text { discharge } \\
\text { heat as a tracer }\end{array}$ \\
\hline
\end{tabular}

seepage meter

\section{DR2 Drain, Washington}

Ground-water/surface-water interactions were studied in the lower reaches of the DR2 Drain, about $200 \mathrm{~m}$ upstream from the confluence with Granger Drain, which flows into the Yakima River in South Central Washington State (Payne et al., 2007). The development of irrigated agriculture in the Yakima Basin led to rising water tables, and the drains were designed to prevent loss of agricultural land. The upper 3 to $9 \mathrm{~m}$ of unconsolidated sediments consist of relatively low hydraulic conductivity clayey silt, silty sand, and very fine sand deposited during Late Pleistocene (Missoula) floods. These deposits are underlain by 5 to $9 \mathrm{~m}$ of alluvial fan and loess material. The lower reach of DR2 Drain intercepts the water table and as a result flows year-round. Mean flow in the drain for the period from March 2003 through September 2004 was $0.14 \mathrm{~m}^{3} \mathrm{~s}^{-1}$, with flows during the summer irrigation season $\left(0.12-0.22 \mathrm{~m}^{3} \mathrm{~s}^{-1}\right.$ mean flow) higher than during the winter nonirrigation season (0.08-0.11 $\mathrm{m}^{3} \mathrm{~s}^{-1}$ mean flow). The climate of DR2 basin is characterized by hot, dry summers and cold winters. Total precipitation for 2004 was $221 \mathrm{~mm}$, with the months of June and August being unusually wet; January, February, and October were slightly wetter than normal; and November was atypically dry.

\section{Merced River, California}

The Lower Merced River Basin, within the Central Valley of California, is approximately $832 \mathrm{~km}^{2}$ and is predominantly almond orchards, corn, grain, and vineyards on the valley floor (Gronberg and Kratzer, 2006). The upstream part of the basin extends eastward into the lower foothills of the Sierra Nevada, where outflow from the Upper Merced River Basin is controlled by a large dam. Alluvial deposits in the eastern part of the valley were derived primarily from the weathering of granitic intrusive rocks of the Sierra Nevada. These deposits, which form broad alluvial fans where the streams enter the valley, are highly permeable, medium- to coarse-grained sands (Gronberg and Kratzer, 2006). Stream-channel deposits along the Merced River consist of coarse sand. The mean annual streamflow for water years (October-September) 1941 through 2005 was $19.5 \mathrm{~m}^{3} \mathrm{~s}^{-1}$; the mean flow for calendar year 2004 was $7.76 \mathrm{~m}^{3} \mathrm{~s}^{-1}$ (Gronberg and Kratzer, 2006). The arid to semiarid climate is characterized by 


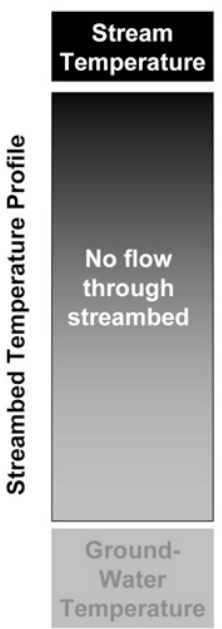

A

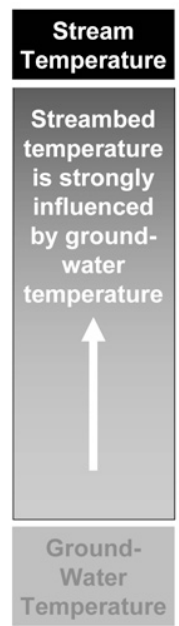

B

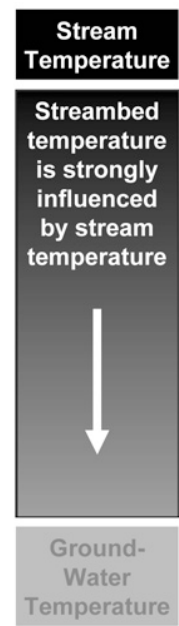

C
Fig. 1. Streambed temperature profiles for (A) a neutral stream, $(B)$ a gaining stream, and $(C)$ a losing stream. The top of each profile is the stream water/streambed interface.

hot summers and mild winters, with a mean annual precipitation (1889-2004) of $310 \mathrm{~mm}$. Eighty percent of the precipitation falls during November through March, with maximum precipitation in December through February. The GW/SW interaction study site on the Merced River is located about $25 \mathrm{~km}$ above its confluence with the San Joaquin River.

\section{Methods}

\section{Using Heat as a Tracer to Estimate Streambed Water Flux}

Using heat as a tracer in conjunction with water-level measurements has been shown to be an effective method for estimating GW/SW exchanges (Silliman and Booth, 1993; Silliman et al., 1995; Constantz and Stonestrom, 2003; Anderson, 2005). This method requires continuously monitoring the temperature and level of the stream, the temperature at multiple depths below the stream water/streambed interface, and the hydraulic head at the depth of the deepest temperature measurements. Heat is transported through the streambed primarily by conduction and advection with the flowing water (Constantz and Stonestrom, 2003). Thus, observations of streambed temperature variations with depth can give qualitative indications of the nature of streambed flux. If there is no water flux through the streambed, heat is transported conductively, and there is a gradual gradation in temperature in the bed from the ground-water temperature below the streambed to the stream-water temperature at the surface (Fig. 1A). When there is upward flow of ground water (a gaining stream), however, the intermediate depth temperatures (Fig. 1B) are influenced more by ground-water temperature relative to the no-streambed-flux case. Conversely, when there is downward flow of stream water into the streambed (a losing stream), the opposite occurs, and intermediate depth temperatures are influenced more by the stream temperature (Fig. 1C). In addition, the extent and rate at which diurnal and seasonal fluctuations in stream-water temperature are propagated into the streambed depend on the water flux and temperature gradient. Upward flow of ground water dampens the temperature fluctuations in the streambed, whereas downward flow of surface water amplifies streambed temperature fluctuations. Quantitative estimates of streambed water flux can be made by matching observed streambed temperatures with simulated temperatures from a numerical model that simulates the flow of water and heat through sediments (Ronan et al., 1998; Niswonger and Prudic, 2003).

Table 1 summarizes the period of monitoring and the number of sites monitored and analyzed in each stream channel. Figure 2 shows the streambed and bank topography, sediment type encountered during piezometer installation, and temperature and head measurement depths for the four watersheds. At the NE, WA, and CA sites, piezometers installed in the streambed were constructed from 5-cm inner diameter (ID) polyvinyl chloride (PVC) pipe with 15-cm-long screens. The IN piezometers were constructed from 3-cm ID PVC. At the IN and WA sites, the piezometers were extended above the highest stream and groundwater level and were open to the atmosphere. The NE piezometers were vented to the atmosphere by plastic tubing that ran under the stream and came out on the stream bank (above flood stage). Because of the size of the Merced River (see Fig. 2D), such installations were not feasible; the piezometers were extended 15 $\mathrm{cm}$ above the river bed and sealed with waterproof caps.

The method of piezometer installation differed from site to site because of the differences in the streambed sediments. At the IN site, piezometer nests were installed at two sites within one transect across the Leary Weber Ditch (Fig. 2A). The piezometers were installed by hydro-jetting (using high-pressure water to flush sediment) inside a 10-cm-diameter PVC casing. The general lithology observed during jetting was recorded. A 30-cm-thick dense, gray, silt layer present at the left side of the channel, at a depth of about $0.5 \mathrm{~m}$, had to be augered through before hydrojetting could continue. This silt layer was encountered at or near the streambed during piezometer installation at several transects along the study reach. Piezometers were sealed with bentonite.

At the NE site, piezometers also were installed by hydro-jetting. A storm during the last week of May caused high flows that washed out the piezometers and associated equipment at all but one site. Thus, long-term temperature records are available only from one location within one transect (Fig. 2B) in Maple Creek.

The piezometers at the WA site were installed in a 10-cm-diameter, hand-augered hole. The hole was held open with a length of 8-cm-ID PVC pipe while the piezometer casing was installed. The annular space was filled with sand to a height of approximately 6 to $15 \mathrm{~cm}$ above the top of the screen. The installation was completed by filling the annular space to the surface of the streambed with bentonite pellets, followed by a short developing process to ensure hydraulic connectivity with the streambed water. Piezometer nests were installed in the center of the streambed of DR2 Drain at two transects spaced about $65 \mathrm{~m}$ apart (Fig. 2C).

At the CA site, the piezometers were installed by hydrojetting inside a 10-cm-diameter PVC pipe and a 5-cm-ID piezometer was lowered to depth. The 10-cm-diameter PVC pipe was then removed, and the unconsolidated alluvial sand in the streambed immediately collapsed around the 5-cmdiameter PVC pipe, eliminating the need for a bentonite seal. 
Long-term temperature and head records were analyzed from one piezometer nest within one transect (Fig. 2D).

The temperature of water in the streams and the piezometers was monitored at a 15 -min (IN, NE, and CA sites) or a 60-min (WA site) recording interval at multiple depths below the streambed by suspending StowAway TidbiT Temperature Loggers (Onset Computer Corp., Pocasset, MA; range: -4 to $30^{\circ} \mathrm{C}$; accuracy: $\pm 0.2^{\circ} \mathrm{C}$ at $20^{\circ} \mathrm{C}$ ) within the piezometer clusters. Water levels in the stream and in each piezometer were monitored continuously using Solinst Leveloggers (range: $4 \mathrm{~m}$; resolution: $0.1 \mathrm{~cm}$; accuracy: $4 \mathrm{~mm}$ ) (Model 3001 F15; Solinst Canada Ltd, Georgetown, Ontario, Canada) and Solinist Barologgers (Model M5), for atmospheric-pressure-change compensation at the same recording interval as for temperature.

One-dimensional (vertical) models of water and heat flow with 0.02-m-thick grid-blocks were developed to simulate temperature and head observations and to estimate GW/SW fluxes through the streambed (Fig. 3). Simulated temperatures were generated from models (Fig. 3) at each of the monitored sites shown in Fig. 2. The top boundary of the model was generally assigned the time-varying observed stream stage and temperature. It was specified as a no-flow boundary during periods of no stream flow at the IN site. When the stream-level data were missing or uncertain (NE and CA), the vertical head gradient observed in the streambed (from piezometers at different elevations) was used to specify model head boundary conditions such that the model head gradient corresponded to the observed streambed head gradient. The bottom boundary was assigned the time-varying deepest observed groundwater head and temperature. No-flow conditions were assigned to the lateral boundaries. The energy transport and water flow model VS2DH (Healy and Ronan, 1996) and its graphical user interface VS2DI (Hsieh et al., 2000) were used to simulate temperatures and heads in the streambeds. Observed temperatures at intermediate depths were generally matched by trial-and-error calibration of the model; however, the extensive data available from the Leary Weber Ditch site made it possible to perform inverse modeling using the universal inverse modeling tool UCODE (Poeter and Hill, 1998) to fit the observed temperatures and heads. In general, typical values of thermal properties and porosity (Stonestrom and Blasch, 2003) can be used so that one simply needs to adjust hydraulic conductivity to obtain good fits to observed temperatures (Niswonger and Prudic, 2003). This is possible because the temperature distribution in the streambed is more sensitive to the water flux (controlled by hydraulic conductivity, a property that varies over several orders of magnitude) than to other properties of the system when streambed water fluxes are greater than about $1 \times$ $10^{-7} \mathrm{~m} \mathrm{~s}^{-1}$ (R. Niswonger, personal communication, 2006).

\section{Seepage Meters}

A seepage meter allows direct measurement of water flux across the streambed surface for a discrete time interval, generally from $1-\mathrm{h}$ to $1-\mathrm{d}$ duration. The device consists of a bottomless cylinder formed from an inverted drum or bucket connected to a collection bag by a length of tubing. The device is pushed into the bed of a lake or stream, and a collection bag containing a known volume of water is attached. The collection bag is removed after a period of
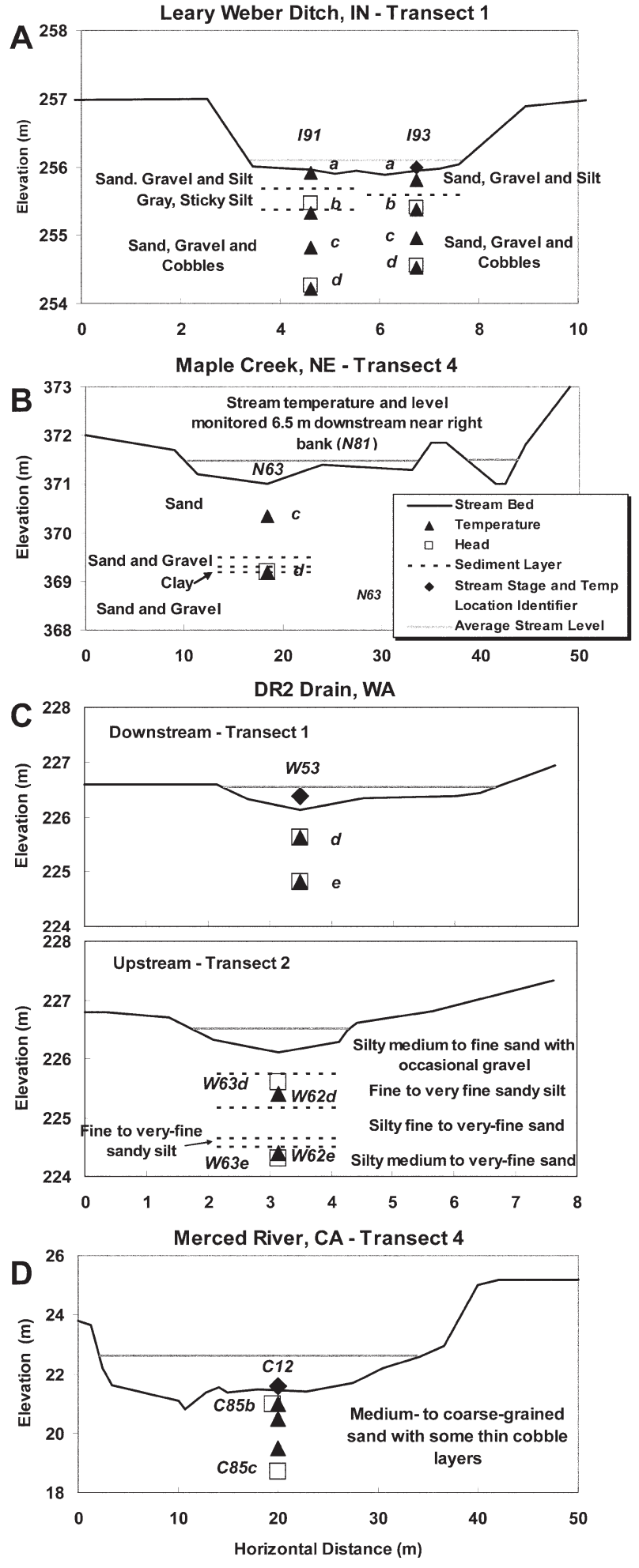

Fig. 2. Stream transects showing streambed topographic profile, temperature and head monitoring locations, and observed lithology (where available).

time, and the rate of vertical ground-water flux through the area of streambed or lake bottom enclosed by the seepage meter is calculated from the change in the volume of water contained in the bag, the length of time elapsed, and the area of the cylinder. An increase in the initial volume of water in the collection bag indicates a posi- 


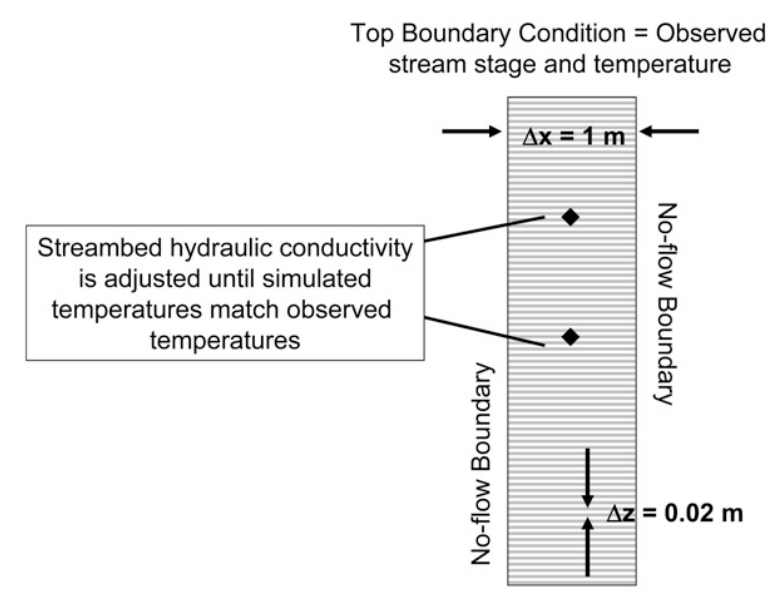

Bottom Boundary Condition $=$ Deepest observed head and temperature

Fig. 3. Framework for one-dimensional vertical modeling of water and heat flow through a streambed ( $\Delta \mathrm{x}$ is the horizontal discretization, and $\Delta z$ is the vertical discretization). The top of the simulated profile is the stream water/streambed interface.

tive flux (ground water to surface water), and a decrease in volume indicates a negative flux (surface water to ground water).

The seepage meter was initially developed to measure losses from irrigation canals (Israelson and Reeve, 1944), and later its use was expanded to measure ground-water discharge into lakes (Lee, 1977; John and Lock, 1977; Rosenberry, 2005; Sebestyen and Schneider, 2001). Because seepage meters provide a quick and simple method for measuring the magnitude and direction of water flux, their use has been expanded to environments other than lakes. Rosenberry and Menheer (2006) have developed a system for calibrating seepage meters in the lab before field use.

This study used conventional seepage meters that were inexpensive and relatively easy to fabricate. Craig (2006) measured seepage at the IN and NE sites in the summer of 2004 using a seepage meter with a scour-prevention carapace that covered the seepage cylinder and the thin-walled bag. In addition, standard drum-type seepage meters with sheltered bags (Zamora, 2006) were used to measure seepage rates at the IN and CA sites. Zamora (2006) tested many seepage meter configurations at the CA site. Her most consistent results were obtained using drums that were $2500 \mathrm{~cm}^{2}$ in cross-sectional area with a $2000 \mathrm{~mL}$ VoidFill packaging bag (Inflatable Packaging Inc., Newton, CT) protected in a perforated storage box (Rubbermaid, Atlanta, GA). Multiple measurements of seepage were made in each streambed transect during each sampling round but could not be made at exactly the same location as the temperature-based flux estimates because of the piezometer installation. Thus, temperature-based flux estimates were compared with all seepage meter measurements made along the transect, with the expectation that they would fall within the observed range of seepage meter fluxes.

\section{Synoptic Discharge Measurements}

Measurements of stream discharge were made upstream and downstream from the GW/SW interaction study reaches. A pygmy current meter (in WA) or a SonTek acoustic doppler velocimeter (in NE and IN) were used to make these measurements.
Measurements were made during high- and low flow-periods at the IN site. At the WA site, changes in flow could not be detected using standard stream gauging techniques because the change in flow was small and was within the uncertainty in discharge measurements. In addition to the physical measurements of stream discharge, Duff et al. (2006) used a bromide-tracer dilution technique to determine discharge at the NE (September 2004) and WA (September 2003) sites. No discharge measurements were made at the CA site because the high flows and large channel of the Merced River made it impractical to detect the small changes in discharge caused by ground-water inflow or outflow.

The difference in discharge over the length of the stream reach was converted to an average unit streambed water flux (cubic meters per second per unit streambed surface area) by dividing the discharge difference by the streambed surface area (reach length times average reach width).

\section{Synoptic Streambed Temperature Survey}

Before the initiation of continuous monitoring, streambed temperatures were measured along 29 parallel transects across Maple Creek, NE, over a 4.5-d period in December 2003. The elevation of the streambed was measured at each sampling point, and temperature was measured at depths from 0 to $1 \mathrm{~m}$ below the streambed about every $3 \mathrm{~m}$ along the transect using a 1-m-long, heavy-duty temperature penetration probe (Model EW-93756-26; Cole-Parmer, Vernon Hills, IL). The probe was pushed into the ground to each individual sample depth, and a temperature measurement was recorded after a steady reading was achieved. Transects were spaced about $9 \mathrm{~m}$ apart. During this period there was a substantial contrast between cold surface water (average $\mathrm{T}$, $3.5^{\circ} \mathrm{C}$; range, $\left.1-6^{\circ} \mathrm{C}\right)$ and warm ground water $\left(\mathrm{T}>11^{\circ} \mathrm{C}\right)$.

\section{Results}

The vertical numerical models were used to estimate streambed water flux by matching simulated temperatures to observed temperatures. The streambed was assigned uniform hydraulic properties unless lithologic logging and head measurements at intermediate depths suggested the presence of multiple layers or lenses of material with different hydraulic properties (such as in IN and the upstream WA location). The best-fit hydraulic conductivities and values of effective porosity and thermal conductivity used in the models are reported in Table 2. The Pearson product $R^{2}$ for each model fit is also reported in Table 2 . When all data were available, comparisons were made between modelestimated streambed fluxes, seepage-meter measured fluxes, and estimates of streambed fluxes based on synoptic stream discharge measurements. Diurnal fluctuations in head were observed at all sites; these may have been caused by evapotranspiration driven changes in head or transducer temperature sensitivity.

\section{Leary Weber Ditch, Indiana}

Stream water levels (stage), observed temperatures, and the head gradients ([deep piezometer head - shallow piezometer head]/vertical distance) in the streambed observed at two sites in the Leary Weber Ditch (Fig. 4) suggest higher streambed flux at 
Table 2. Summary of model information, parameter estimates, and calibrated model Pearson product correlation coefficients.

\begin{tabular}{|c|c|c|c|c|c|c|}
\hline $\begin{array}{l}\text { Location } \\
\text { simulated }\end{array}$ & Data used for model calibration & $\begin{array}{l}\text { Layer } \\
\text { thickness }\end{array}$ & $\begin{array}{l}\text { Fitted vertical hydraulic conductivity } \\
\text { of streambed sediments }\end{array}$ & $\begin{array}{l}\text { Effective } \\
\text { porosity† }\end{array}$ & $\begin{array}{c}\text { Thermal } \\
\text { conductivity† }\end{array}$ & $\begin{array}{l}\text { Calibrated } \\
\text { model }\left(R^{2}\right)\end{array}$ \\
\hline & & $\mathrm{m}$ & $\mathrm{m} \mathrm{s}^{-1}$ & & $\mathrm{~W} / \mathrm{m}^{\circ} \mathrm{C}$ & \\
\hline \multirow[t]{3}{*}{ IN, left } & heads at one depth, temperatures at & 0.3 & $1.0 \times 10^{-4}$ & 0.25 & 2.2 & 0.96 \\
\hline & & 0.3 & $6.8 \times 10^{-6}$ & 0.40 & 1.4 & \\
\hline & & 1.2 & $7.9 \times 10^{-3}$ & 0.30 & 2.0 & \\
\hline \multirow[t]{2}{*}{ IN, right } & $\begin{array}{l}\text { heads at one depth, temperatures at } \\
\text { three depths }\end{array}$ & 0.3 & $1.0 \times 10^{-4}$ & 0.25 & 2.2 & 0.90 \\
\hline & & 1.1 & $7.9 \times 10^{-3}$ & 0.30 & 2.0 & \\
\hline NE & temperatures at one depth & 1.8 & $7.5 \times 10^{-5}$ & 0.30 & 1.8 & 0.66 \\
\hline \multirow[t]{2}{*}{ WA, upstream } & $\begin{array}{l}\text { heads at one depth, temperatures at } \\
\text { one depth }\end{array}$ & 0.4 & $1.3 \times 10^{-6}$ & 0.40 & 1.4 & 0.89 \\
\hline & & 1.4 & $1.3 \times 10^{-5}$ & 0.38 & 1.4 & \\
\hline WA, downstream & $\begin{array}{l}\text { heads at one depth, temperatures at } \\
\text { one depth }\end{array}$ & 1.3 & $4.5 \times 10^{-6}$ & 0.38 & 1.4 & 0.94 \\
\hline CA & temperatures at two depths & 2.0 & $1.2 \times 10^{-5} / 1.2 \times 10^{-4}$ & 0.30 & 1.8 & 0.99 \\
\hline
\end{tabular}

† Based on literature values (Stonestrom and Blasch, 2003; Niswonger and Prudic, 2003).

the right piezometer nest than at the left piezometer nest. Positive head-gradient values indicate upward ground-water flow to the stream, and negative head-gradient values indicate downward stream-water flow into the streambed or downward flow of ground water during stream dry periods. When upward ground-water flux is appreciable, observed temperatures within the profile approach the temperatures observed at the deepest measured point. Conversely, when there is appreciable downward flow of surface water, temperatures within the profile approach the stream-water temperature. Thus, comparing the intermediate depth temperature to the temperatures of the stream water and the deepest measured point gives a qualitative sense of the relative amount and direction of flux through the streambed. For example, during the early part of the temperature record (March-July 2004) at the left piezometer in Leary Weber Ditch (Fig. 4B), the 0.1-m depth temperature is close to that of stream water. At the right piezometer (Fig. 4C), the $0.1-\mathrm{m}$ depth temperatures are cooler than stream water and approach the deeper temperature values within the streambed profile. The small vertical head gradients observed in the right piezometer suggest a high hydraulic conductivity. This evidence suggests that there is substantially more upward flow at the right piezometer location than at the left. A silt layer was detected at about 0.5-m depth during coring at the left side of the channel but not at the right. Fig. 2A supports this conclusion. Ground-water discharge to the ditch seems to be focused toward the high conductivity zone in the streambed, resulting in higher streambed flux at the right location than at the left.

Closer examination of the data for March through July (Fig. $4 \mathrm{~B}$ and $4 \mathrm{C}$ ) shows that in late-May to mid-June there were three sharp, short-lived reversals in head gradient (induced by highstreamflow events) (Fig. 4A) that coincided with rapid upward spikes in temperature as relatively warmer stream water entered the streambed. These spikes are more pronounced in the temperature record for the right piezometer nest (Fig. 4C) (where no silt layer was encountered; Fig. 2A) than for the left nest, suggesting that water can move easily between the stream and the subsurface flow system at this location. Thus, during the wet season, ground-water discharge to the stream is focused at locations of highest streambed conductivity (i.e., where no silt layer is present); during high-runoff events, however, rapid rise in stream level causes a reversal in head gradient, and stream water is pushed into the streambed. Temperatures measured in the right bank of Leary Weber Ditch (not shown) also showed a slight increase during the June flood event, suggesting that stream water also moved into the stream bank as a result of the high flow. During the dry season (August-October 2004), stream and ground-water levels declined, causing the ditch to lose water by downward seepage through the streambed as suggested by the similarity of streambed temperatures to stream-water temperatures during this period. Eventually, the ground-water level dropped below the streambed, and the ditch became dry. As the wet season began (November-December 2004), there was a period of alternating downward and upward seepage through the streambed in response to rainfall and intervening periods of no rainfall. Eventually, because of recharge, ground-water levels rose high enough to maintain GW flow to the ditch.

One-dimensional vertical models of heat and water flow were constructed for the left and right piezometer nest locations. The models were calibrated simultaneously using the inverse model UCODE (Poeter and Hill, 1998) by assuming that the bottom and top sediment layers had the same hydraulic conductivity $(\mathrm{K})$ at both locations. Simultaneous calibration of the two vertical models provided sufficient information to estimate $\mathrm{K}$ values of the stream bottom sediments, the overlying silt layer, and the top sediments (Table 2). The upper and lower 95\% confidence intervals for the hydraulic conductivities of the streambed sediments and silt layer (and consequently the streambed flux estimates) were within $2 \%$ of the values reported in Table 2 . However, the inverse modeling results showed that the model fit was least sensitive to changes in the hydraulic conductivity of the bottom sediments because flow through the streambed was controlled by the lower hydraulic conductivities of the overlying layers. Thus, the inverse-model estimate of $\mathrm{K}$ for the lower layer is poorly constrained relative to that for the other layers (upper and lower $95 \%$ confidence intervals were $\pm 15 \%$ of the calibrated value). Observed and best-fit simulated temperatures are shown in Fig. 5.

The estimated fluxes vary with location in the stream transect. Fluxes at the right piezometer nest location (mean flux, $3.7 \times$ $10^{-6} \mathrm{~m} \mathrm{~s}^{-1}$; SD, $7.6 \times 10^{-6} \mathrm{~m} \mathrm{~s}^{-1}$ ), the only location at which no 
A
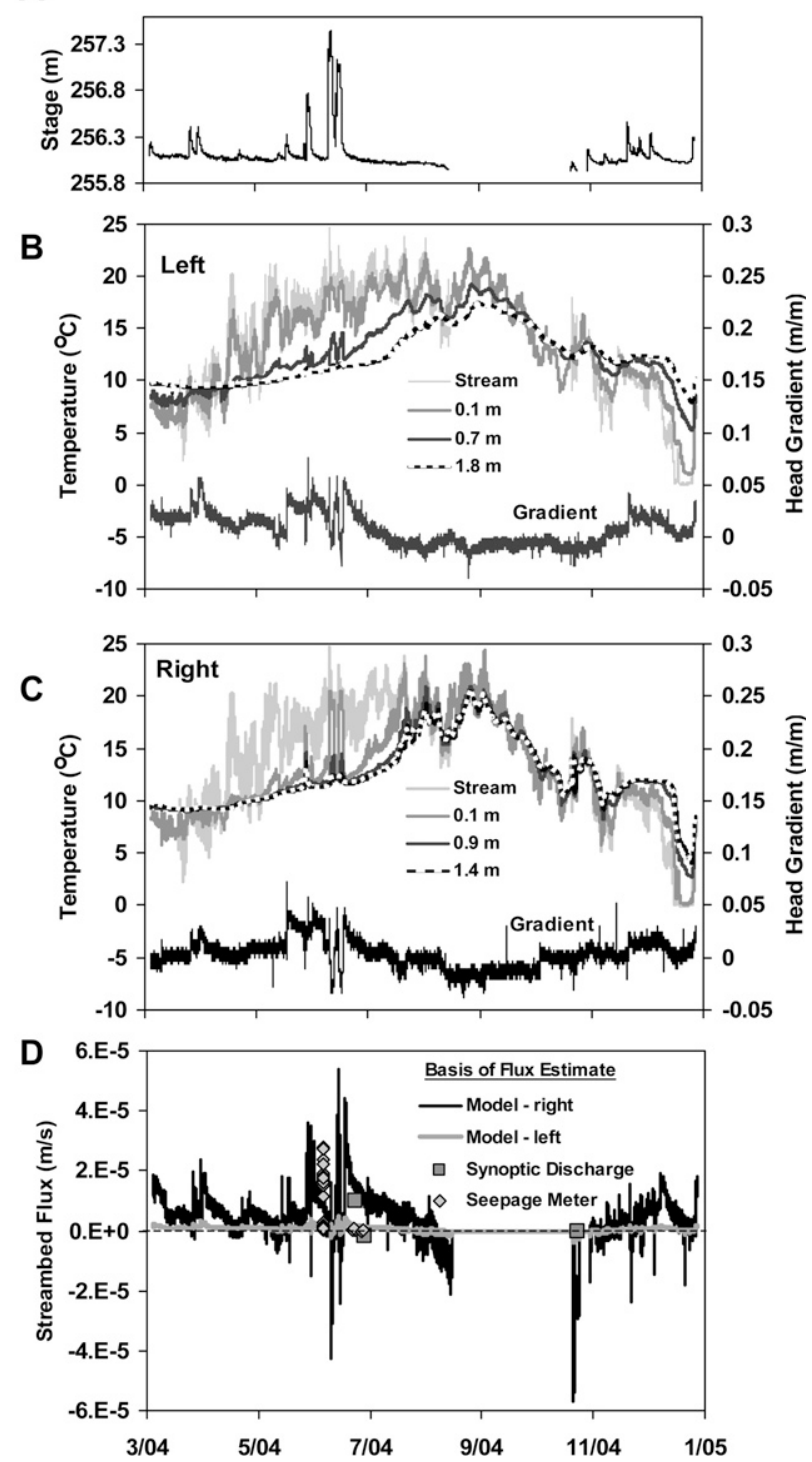

Fig. 4. Plots of observed (A) stream stage, (B) left piezometer nest temperatures and head gradient, $(C)$ right piezometer nest temperature and head gradient, and (D) estimated streambed flux (positive for upward flow) in Leary Weber Ditch, IN.

underlying silt layer was detected, are almost an order of magnitude larger than the left nest fluxes (mean flux, $5.2 \times 10^{-7} \mathrm{~m} \mathrm{~s}^{-1}$; $\mathrm{SD}, 7.7 \times 10^{-7} \mathrm{~m} \mathrm{~s}^{-1}$ ). These continuous estimates of flux (Fig. 4D) demonstrate the spatial variability of GW/SW interactions in the streambed and illustrate the dynamic nature of GW/SW interactions, with flow reversals occurring during high-flow events and as a result of seasonal fluctuations in stream and ground-water levels.

The model-estimated fluxes were compared with fluxes measured with a seepage meter and those calculated on the basis of discharge measurement. Early June seepage-meter measurements (Fig. 4D) made at several locations along the transect showed a wide range of values due to spatial variability (Craig, 2006); however, it seems that the model-estimated fluxes fall within the distribution of fluxes measured along the transect with seepage meters. The seepage-meter measurements show a cluster of high flux values
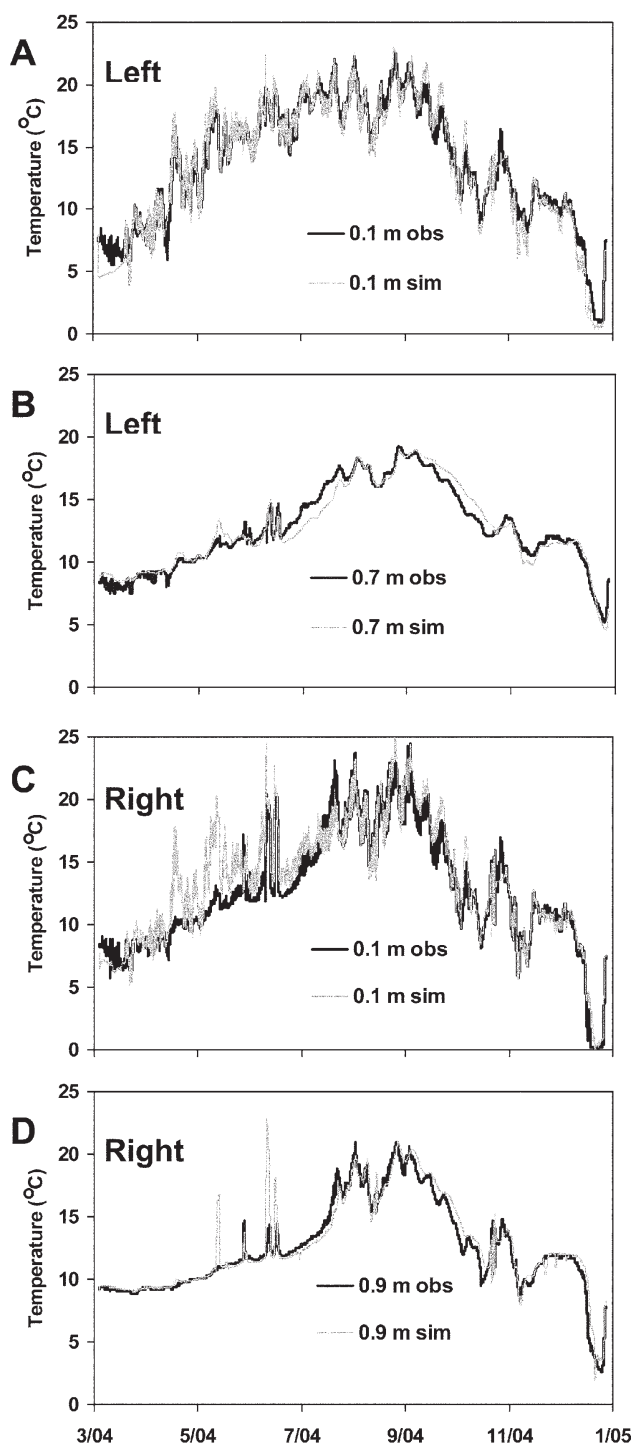

Fig. 5. Observed (obs) and simulated (sim) temperatures at Leary Weber Ditch, IN for (A) the left piezometer 0.1-m depth, (B) the left piezometer $0.7-\mathrm{m}$ depth, $(\mathrm{C})$ the right piezometer $0.1-\mathrm{m}$ depth, and (D) the right piezometer 0.9-m depth.

that are in the range of the model-estimated fluxes for the right piezometer location and a cluster of low values that approach the model-estimated fluxes for the left piezometer location. Seepagemeter measurements made in late June, after the high-streamflow event, are much lower than the model estimates of flux. This could be because the ground-water flow to the ditch decreased more rapidly than predicted after floods because of multidimensional flow effects not included in the model and/or because the streambed zone of high flux was not encountered by the seepage meters.

Maps of ground-water levels coincident with stream discharge measurement times (Fig. 6) illustrate the seasonally varying nature of GW/SW interactions. The data and analysis presented here (left and right locations) correspond to the $\mathrm{T} 1$ transect location in Fig. 6 . The ditch was gaining water on 25 June, as indicated by the upstream bends in the contour lines (Fig. 6A), and the dischargebased average flux estimate for the reach was $1 \times 10^{-5} \mathrm{~m} \mathrm{~s}^{-1}$ greater 


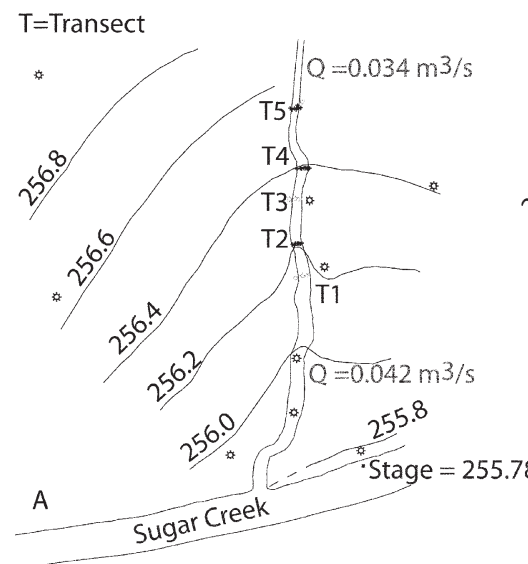

June 25, 2004

* Piezometer

256.0 Ground-water level (meters above sea level) contour, contour interval is $0.2 \mathrm{~m}$

$Q$ Stream discharge, in cubic meters per second

T1 Transect number and location

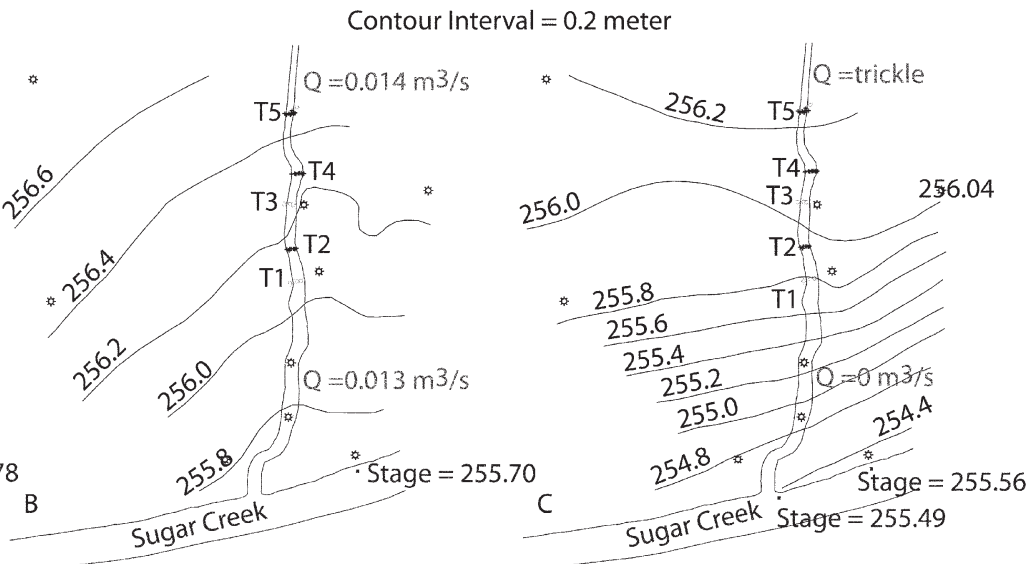

June 30, 2004

October 26, 2004

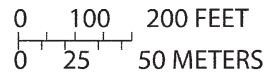

Fig. 6. Maps showing Leary Weber Ditch, IN study transects (temperature data are from T1), discharge measurements, and ground-water level contours for three synoptic measurement times: (A) 25 June 2004; (B) 30 June 2004; and (C) 26 Oct. 2004.

than the model-based estimate for the left location and less than the model estimate for the right location (Fig. 4D). The dischargebased estimate of flux on 30 June suggests that for the reach as a whole, the flux was neutral or slightly negative (flux estimate, -1.6 $\left.\times 10^{-6} \mathrm{~m} \mathrm{~s}^{-1}\right)$. The model-based estimates suggest that there was little inflow to the ditch at the low-hydraulic conductivity streambed location but still substantial inflow to the ditch at the high hydraulic-conductivity streambed location (Fig. 4D). The varying shape of the ground-water level contours near the ditch in Fig. 6B suggests a complex interaction between ground water and surface water on 30 June. The upper part of the reach may have been losing water, whereas the lower part of the reach may have been gaining water at this time. Model estimates may be representative of a gaining section of the reach, or the flow in the streambed during this period may have been influenced by flow in the horizontal direction, leading to errors in streambed flux estimates obtained from the one-dimensional vertical model. At the end of October, ground-water levels had dropped below the streambed, groundwater flow was toward Sugar Creek (Fig. 6C), and the model- and discharge-based flux estimates were zero. These results indicate that there is considerable temporal and spatial variability in GW/ SW fluxes to Leary Weber Ditch, with substantial ground-water contributions to streamflow taking place during the wet season through local, high-conductivity zones in the streambed. During high-streamflow events and during the early part of the dry season, however, Leary Weber Ditch loses water to the streambed, with the greatest losses occurring in the high hydraulic-conductivity zones in the streambed.

\section{Maple Creek, Nebraska}

A detailed synoptic temperature survey of the Maple Creek streambed was made before the initiation of continuous measurements of temperature and head. A three-dimensional compilation of each two-dimensional transect of temperature and elevation data from the survey made along 29 transects during December 2003 is shown in Fig. 7. Because of the large temperature contrast between the warm ground water $\left(>11^{\circ} \mathrm{C}\right)$ and the cool surface water (average, $3.5^{\circ} \mathrm{C}$; range, $1.3-5.9^{\circ} \mathrm{C}$ ), surface water temperature variations during the survey did not have a substantial effect on the trends observed in the streambed. Streambed temperatures in the upstream part of the survey reach (150-250 m) were relatively warm, suggesting high upward flux of ground water into the creek. In the central part of the reach (50-150 m), the relatively cold streambed temperatures suggest that there was little upward flux of ground water and possibly even downward flux of cold surface water into the streambed at some locations. At the lower end of the reach (below $50 \mathrm{~m}$ ), the streambed became warmer, suggesting increased upward ground-water flux. These measurements and observations suggest significant spatial variability in streambed fluxes in Maple Creek. This spatial variability is due to a combination of changes in streambed hydraulic conductivity, streambed morphology, and variations in ground-water head relative to stream elevation (Craig, 2006).

Temperature and head were monitored continuously in the center of a transect (Fig. 2B) in the upper part of the survey reach (Fig. 7). The streambed sediments were primarily sand and gravel. Seasonal and diurnal fluctuations in streambed temperatures at Maple Creek (Fig. 8B) were similar to those observed at Leary Weber Ditch; however, the 2-m-depth temperature was almost constant throughout the period of observation. For most of the period of record, the $0.7-\mathrm{m}$ depth temperatures were identical to the $2-\mathrm{m}$ temperatures, suggesting upwelling of water through the streambed. During high streamflows in May and July 2004 (Fig. 8A), the 0.7 -m-depth temperatures rose rapidly to the observed stream temperatures, indicating flux of stream water into the streambed. This flux is substantiated by the observed negative head gradients. However, the influx of streamwater into the streambed did not 


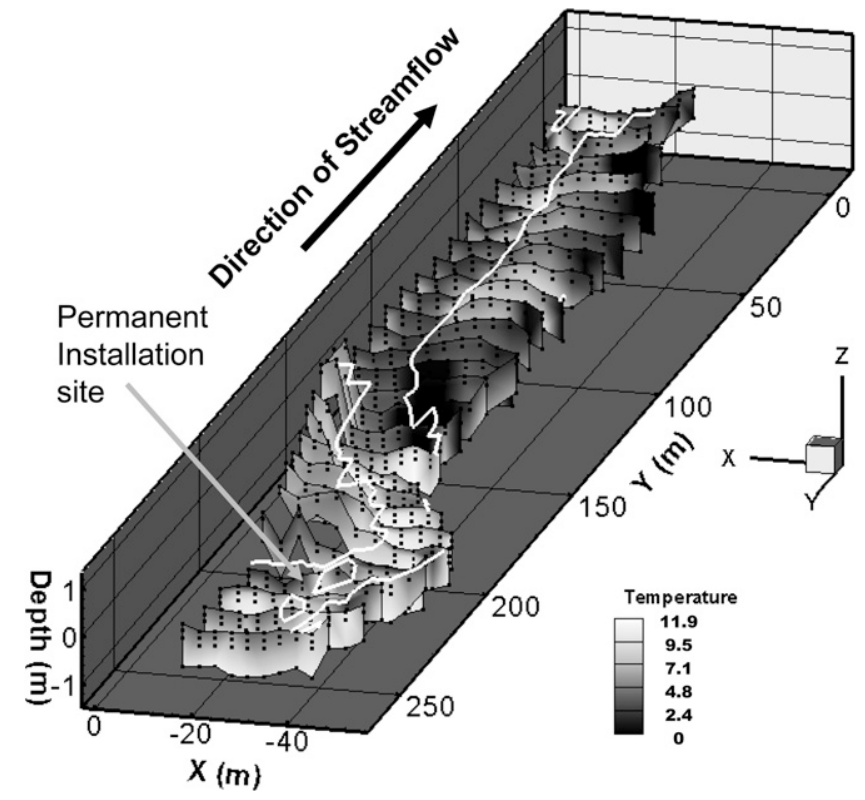

Fig. 7. A three-dimensional representation of observed temperatures along 29 transects in the streambed of Maple Creek, NE, for December 2003. Each black dot is a temperature probe measurement location. The white lines are the stream banks (the left bank was not within the area surveyed below the 100-m reach distance).

A
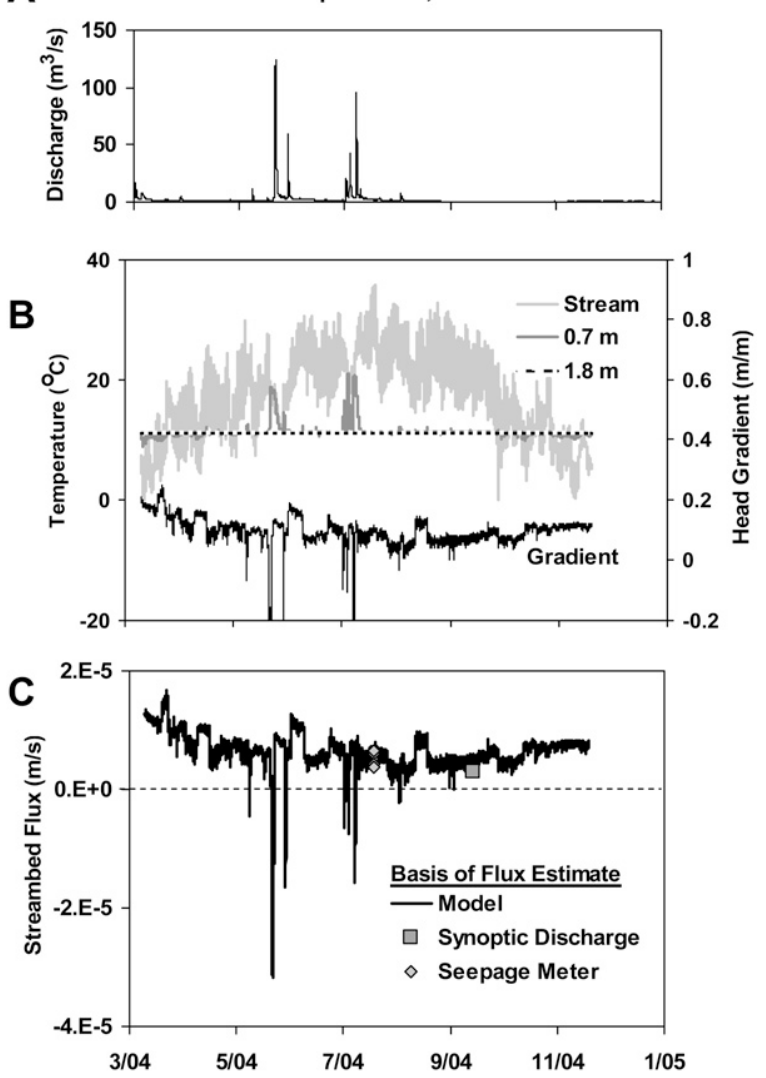

Fig. 8. Plots of (A) observed stream discharge (stage measurements were not available because of instrument damage during the May highflow event), (B) temperature and head gradient, and (C) estimated streambed fluxes (positive for upward flow) in Maple Creek, NE.

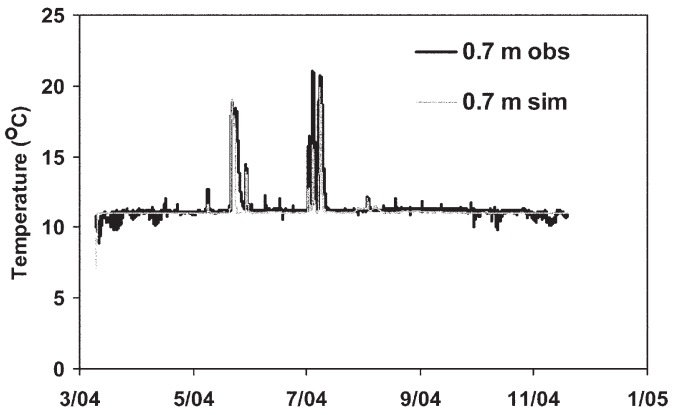

Fig. 9. Observed (obs) and simulated (sim) temperatures in the Maple Creek, NE streambed at a depth of $0.7 \mathrm{~m}$.

penetrate the 2-m depth, possibly because of the presence of a thin clay layer (Fig. 2B). Thus, this site, like Leary Weber Ditch, displays temporal variability and flow reversals in response to high flows. Because instrumentation was lost during the large storm in May 2004, streambed temperatures and fluctuations could not be evaluated for any other sites at Maple Creek.

The estimated streambed fluxes obtained by matching observed and simulated temperatures (Fig. 9) at Maple Creek using a one-dimensional vertical model of water and heat flow ranged from $-3.2 \times 10^{-5} \mathrm{~m} \mathrm{~s}^{-1}$ to $1.7 \times 10^{-5} \mathrm{~m} \mathrm{~s}^{-1}$, with a mean of $6.5 \times$ $10^{-6} \mathrm{~m} \mathrm{~s}^{-1}$ (Fig. 8C). These fluxes were generally positive and upward for most of the year, but large downward fluxes occurred during high-streamflow events, pushing stream water into the streambed. Head gradient reversals were also observed in observation wells on the bank of the creek, confirming that these downward fluxes are not simply a result of a short-circuit pathway for water attributed to disturbance of the streambed by piezometer installation. The heat-flow model-based flux estimates (Fig. 8C) are within the range of values measured at this transect using seepage meters (Craig, 2006) and are close to estimates of flux based on changes in discharge along the reach determined from a tracer test (Duff et al., 2006). Thus, at this site, we observed generally high upward flux through a relatively high hydraulic-conductivity streambed with short periods of flow reversal during high streamflow.

\section{DR2 Drain, Washington}

The observed head gradients, temperatures, and stream levels in the DR2 Drain for the period from July to December 2004 (Fig. 10) suggest that the drain was always gaining ground water; there were no head gradient reversals or temperature spikes like those observed at the IN and NE sites. The head gradient at this site was substantially larger than that at any of the other studied sites, suggesting a low-hydraulic-conductivity streambed resistant to water flux, consistent with the silty, fine sand deposits present in the streambed (Fig. 2C). Heads measured in the deepest piezometers were on the order of $0.5 \mathrm{~m}$ higher than the stream level, reflecting artesian conditions at the site and requiring tall risers to be added to the piezometers. During the winter, this resulted in a large column of water in the piezometer that was exposed to cold air. An unstable column of cold, dense water developed on top of the warmer column of water in contact with the ground water. This resulted in turnover of the water in the piezometer, as illustrated by the greater noise visible in the temperature plots beginning in 
September caused by diurnal temperature fluctuations observed at all depths from September onward (Fig. 8C and 10B). Thus, the water temperature in the piezometer was no longer in equilibrium with the temperature of the water in the adjacent sediments. In spite of this, it was possible to match the early part of the record and use the fitted hydraulic conductivity and observed heads to estimate flux throughout the observation period (Fig. 11).

The estimated streambed fluxes at DR2 Drain are relatively small. At the upstream site, the fluxes ranged from $1.0 \times 10^{-6}$ $\mathrm{m} \mathrm{s}^{-1}$ to $1.5 \times 10^{-6} \mathrm{~m} \mathrm{~s}^{-1}$ (mean, $1.2 \times 10^{-6} \mathrm{~m} \mathrm{~s}^{-1}$ ); fluxes at the downstream site ranged from $9.8 \times 10^{-7} \mathrm{~m} \mathrm{~s}^{-1}$ to $1.6 \times 10^{-6} \mathrm{~m} \mathrm{~s}^{-1}$ (mean, $1.3 \times 10^{-6} \mathrm{~m} \mathrm{~s}^{-1}$ ). Estimated fluxes at DR2 Drain show less spatial and temporal variability than fluxes at other studied sites; however, a flux estimate from tracer-test based discharge measurements made above and below the DR2 Drain GW/ SW study reach in September 2003 was on the order of $7 \times$ $10^{-6} \mathrm{~m} \mathrm{~s}^{-1}$ (Duff et al., 2006), about five times greater than the estimate based on continuous temperature data. The small fluxes are not in agreement with the overall water balance for the site that indicated substantial ground-water inflow to DR2 Drain (Capel et al., 2008). This discrepancy between the streambed flux estimates obtained from the temperature modeling and other flux estimates suggests that most of the ground-water inflow to DR2 must be occurring outside of the monitored streambed locations. Inflow to DR2 may be focused (as at Leary Weber Ditch, IN) at locations of higher streambed hydraulic conductivity or along conduits such as bedding plane fractures and lenses of coarse-grained stream deposits. The monitoring sites did not coincide with any of these ground-water discharge points. Hydraulic head data from the upstream DR2 site suggest that there was a relatively low hydraulic conductivity layer overlying a high conductivity layer in the streambed (Table 2). Under such conditions, it is likely that there would be lateral flow beneath the low conductivity layer, with discharge focused toward any holes or cracks in the layer, analogous to the IN site. The layered nature of the Missoula flood silt deposits would create strong anisotropy of hydraulic conductivity resulting in considerable horizontal flow of ground water to the drain relative to vertical flow, and GW/ SW interactions may have occurred primarily by lateral inflow into the sides of the drain rather than by upward flux in the center of the drain.

\section{Merced River, California}

The Merced River differs from the other three study sites in that it is larger, with higher flows and smaller hydraulic gradients in the streambed. Flows in the study reach are controlled by an upstream dam, where large releases of water are typically made during the spring snowmelt period and sometimes during the wet winter season (Fig. 12A). Like the IN and NE sites, the transect monitored on the Merced River (Fig. 2D) displayed reversals in head gradient and streambed flux in response to these high flows. During the high-streamflow event in May, the stream and streambed temperatures were similar and streambed head gradient was negative (Fig. 12), suggesting downward flux of stream water into the bed. This hypothesis of downward flux of stream water is substantiated by continuous measurements
DR2 Drain, WA
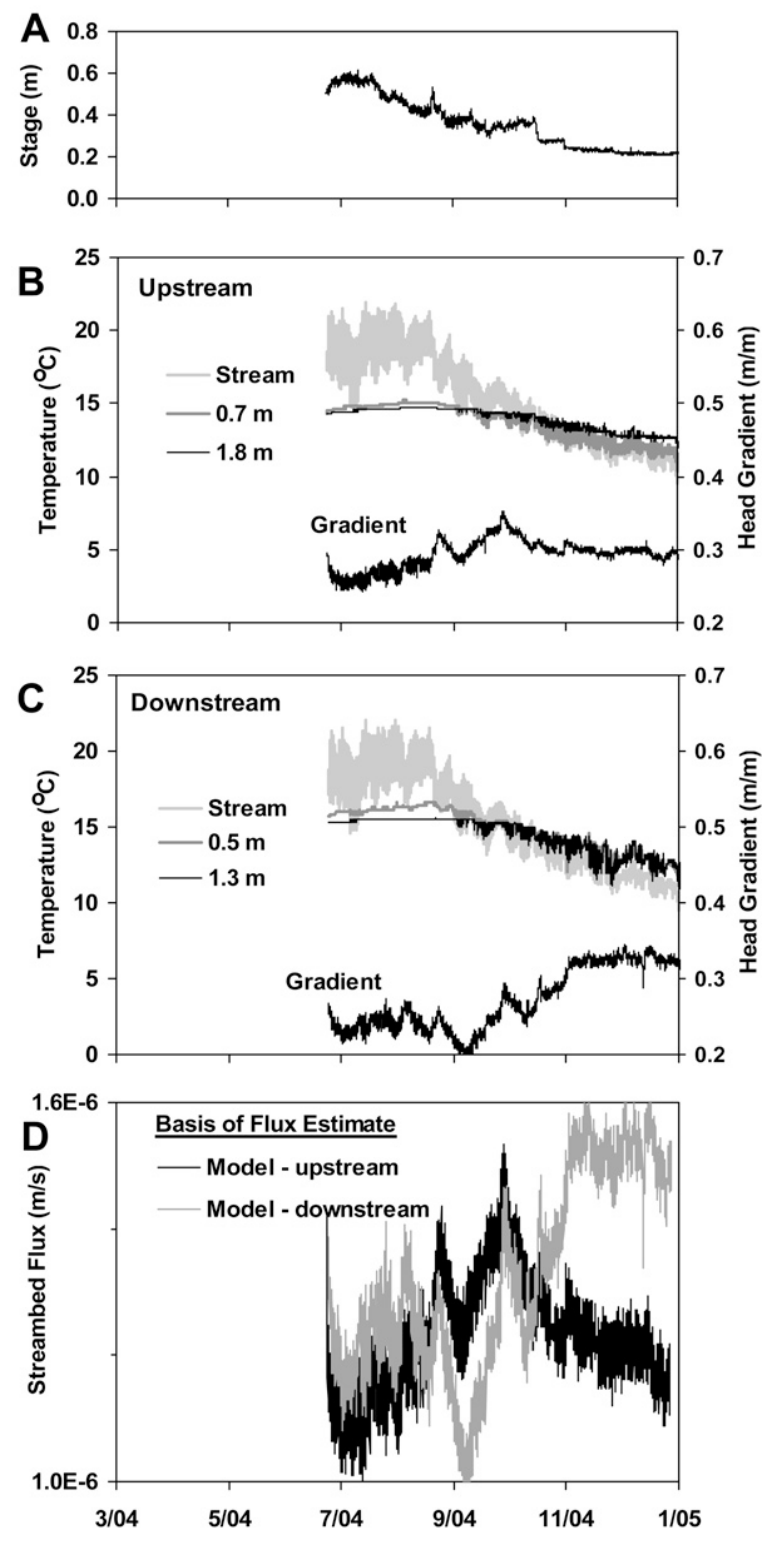

Fig. 10. Plots of observed (A) stream stage, (B) upstream transect temperature and head gradient, (C) downstream transect temperature and head gradient, and (D) estimated streambed flux in DR2 Drain, WA.

of specific conductance (see Fig. 5) (Puckett et al., 2008). The specific conductance in the streambed decreased to stream water values during high-streamflow events and returned to background levels when upward ground-water flux resumed.

The observed temperature record and the water and heat-flow modeling results illustrate an interesting phenomenon. For the period from March to mid-October 2004, the intermediate-depth streambed temperatures (0.5- and 1.0-m depths) were distributed fairly evenly between the bottom (2-m depth) and stream temperatures, suggesting small water fluxes through the streambed (see Fig. 1A). After the October high-flow event, the intermediate-depth temperatures closely follow the deepest 2.0-m depth temperatures, suggesting significantly greater upward flux of ground water dur- 

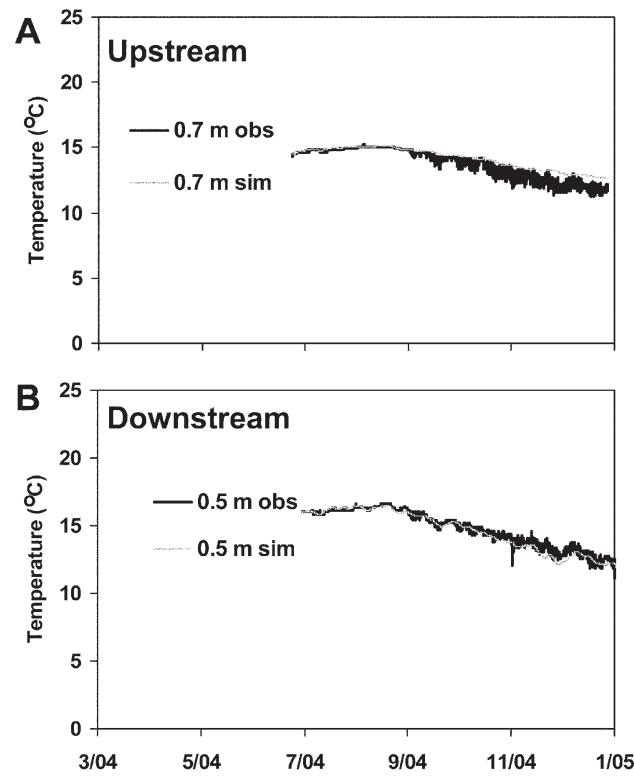

Fig. 11. Observed (obs) and simulated (sim) temperatures in the DR2 Drain, WA streambed for (A) a depth of $0.7 \mathrm{~m}$ at the upstream site and (B) a depth of $0.5 \mathrm{~m}$ at the downstream site.

ing this period (see Fig. 1B). Model simulation results confirmed this hypothesis. March to October temperature observations could be matched using a streambed hydraulic conductivity of $1.2 \times 10^{-5} \mathrm{~m} \mathrm{~s}^{-1}$; however, the simulated values did not match
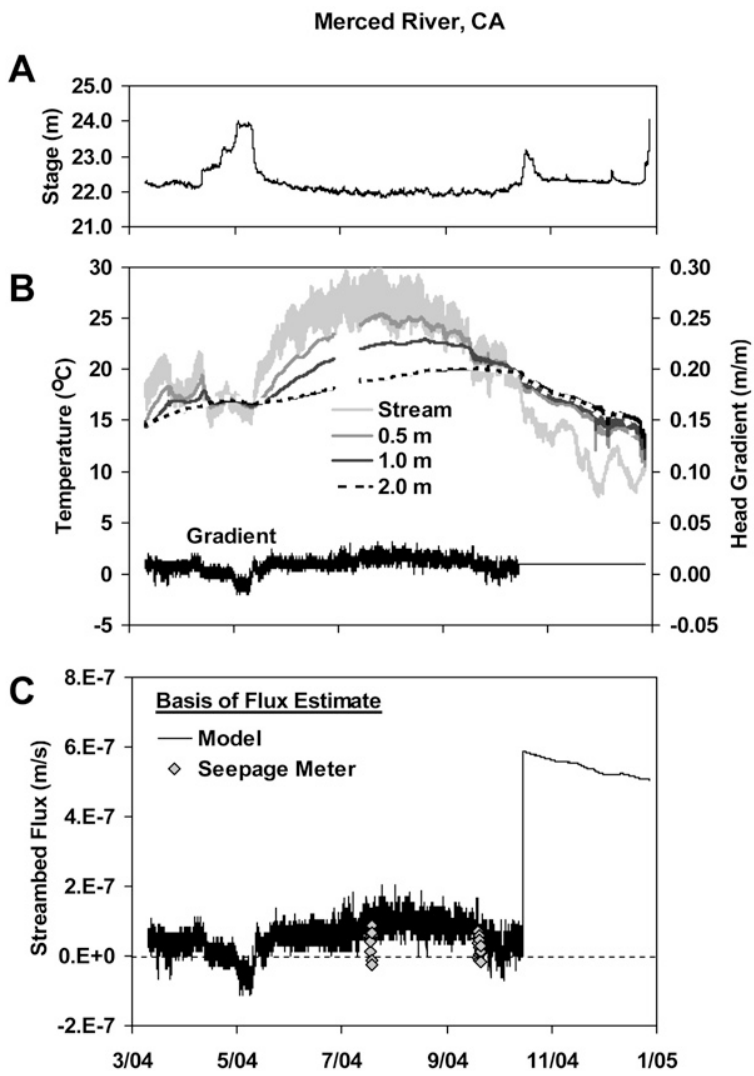

Fig. 12. Plots of observed (A) stream stage, (B) temperature and head gradient, and (C) estimated streambed flux (positive for upward flow) in Merced River, CA. observed values for the period after the high flow event (Fig. 13A). To match this second part of the record, the streambed hydraulic conductivity had to be increased by an order of magnitude on 18 October (Fig. 13B), and hydraulic gradient in the streambed had to be positive (an average gradient of $0.01 \mathrm{~m} \mathrm{~m}^{-1}$ was assumed). This suggests that the October high-flow event and subsequent higher-than-normal streamflows (Fig. 12A) may have changed the character of the streambed, possibly removing a lower conductivity material that was clogging the streambed. Sediments at this site were predominantly medium- to coarse-grained sand (Fig. 2D) and were observed to be dynamic, with moving bedforms and considerable bed movement and scour occurring during seepagemeter measurements (Zamora, 2006). Flows on the Merced River in 2004 were considerably lower than the long-term average flows, and this low-flow regime could have resulted in deposition of finegrained sediments that clogged the streambed.

The streambed flux estimates for the Merced River (Fig. 12C) were small compared with fluxes at the other sites and ranged from $-1.1 \times 10^{-7} \mathrm{~m} \mathrm{~s}^{-1}$ to $5.9 \times 10^{-7} \mathrm{~m} \mathrm{~s}^{-1}$ (mean, $1.8 \times 10^{-7} \mathrm{~m} \mathrm{~s}^{-1}$ ).

Seepage-meter measurements of flux made at six locations in the streambed, encompassing the temperature measurement site, are shown in Fig. 12C. In general, the seepage meter measurements and model estimates of flux are close, although the model estimates are slightly larger. Seepage meter measurements may underestimate actual streambed flux by as much as $15 \%$, as shown by Zamora (2006) in tests conducted in a controlled laboratory seepage tank. The range in seepage meter measurements of flux reflects the spatial variability in flux at this site. No seepage meter measurements were available for the period after the October high-flow event to check the validity of the increase in streambed flux suggested by observed temperatures and model results.

\section{Discussion}

\section{Model Results}

Using heat as a tracer at the four agricultural sites made it possible to make long-term, continuous estimates of the GW/SW fluxes and to demonstrate the temporal and spatial variability of GW/SW interactions in the watersheds. Observation and analysis documented seasonal reversals in streambed flux, high-streamflowinduced reversals in streambed flux, and focusing of flux toward relatively high conductivity zones of the streambed. In IN, one of the instrumented piezometer nests was located at a site of high flux (the right-hand site). It seems, however, that in WA the instrumented sites did not intersect the zones of high streambed flux. The synoptic temperature survey conducted in NE was an effective method for characterizing variability in streambed flux, and surveys of this type can be used to identify potential sites for continuous monitoring of temperature and head. Reconnaissance measurements of head and temperature should be made before permanent installation of equipment so that appropriate instrumentation locations can be identified and preliminary model simulations can be used to design the monitoring network (Constantz and Stonestrom, 2003; Niswonger and Prudic, 2003).

Constantz (1998) successfully identified stream reaches with substantial transient bank storage through analysis of 
stream temperatures during bank-storage releases after peak streamflows. In this study, continuous streambed temperature measurements showed that at three of the sites (IN, NE, and CA), high streamflows pushed substantial amounts of stream water into the streambed sediments and into stream banks.

In general, model-estimated fluxes fell within the range of values obtained from other independent measures of flux. Estimated streambed hydraulic conductivities (Table 2) were within ranges expected for the types of sediments encountered at each site. The only exception was the high hydraulic-conductivity value for the lowest layer at the IN site. Flow through the streambed was controlled by the $\mathrm{K}$ of the overlying layers, and the inverse solution was not sensitive to the bottom $\mathrm{K}$ value, resulting in a model estimate that was too large.

As with any modeling effort, there are uncertainties and limitations associated with the analysis. Simultaneously using temperature and head measurements (as opposed to head measurements alone) made it possible to obtain model-estimated streambed fluxes. Experience from this study showed that it can be challenging to obtain high-quality head measurements in streambeds where head differences are sometimes on the order of a few centimeters or less (especially in coarse sediment). Any errors caused by surveying, disturbance of pressure transducers during water sampling, or poor reference pressure can lead to incorrect head gradients and erroneous conclusions regarding the direction of flow through the streambed. However, the availability of temperature measurements can resolve these discrepancies and uncertainties. A reasonable model fit to observed temperatures can be obtained only when the simulated flux through the streambed is realistic, making this a relatively well constrained modeling exercise.

All of the simulations presented here assumed vertical, onedimensional flow through the streambed. The results suggest that in some environments there may be substantial focusing of flux toward zones of high hydraulic conductivity in the streambed. In reality, flow in a streambed is multidimensional. Essaid et al. (2006) used two-dimensional modeling and data from the Leary Weber Ditch, IN, transect to illustrate that flow in the streambed was horizontal beneath the silt layer and focused toward the zone where no silt was present.

\section{Comparison of Sites}

The four agricultural sites studied vary from humid watersheds in the Midwest (IN and NE) to arid, irrigated watersheds in the West (WA and CA). Streambed sediments varied from finegrained material (WA) to coarse-grained material with silt layers (IN) and without (NE and CA). In general, all study sites were on gaining reaches of streams. Temperature-based flux estimates indicated that basins that experienced sudden high streamflows (IN, $\mathrm{NE}$, and $\mathrm{CA}$ ) demonstrated short episodes during which stream water moved into the streambed, whereas DR2 Drain, WA, which has a relatively low-conductivity streambed, did not experience sudden high flows and did not show flux direction reversal during the period of record. Leary Weber Ditch, IN, the only intermittent stream, showed a period of surface-water loss to ground water during the dry season because of reduced regional ground-water levels.
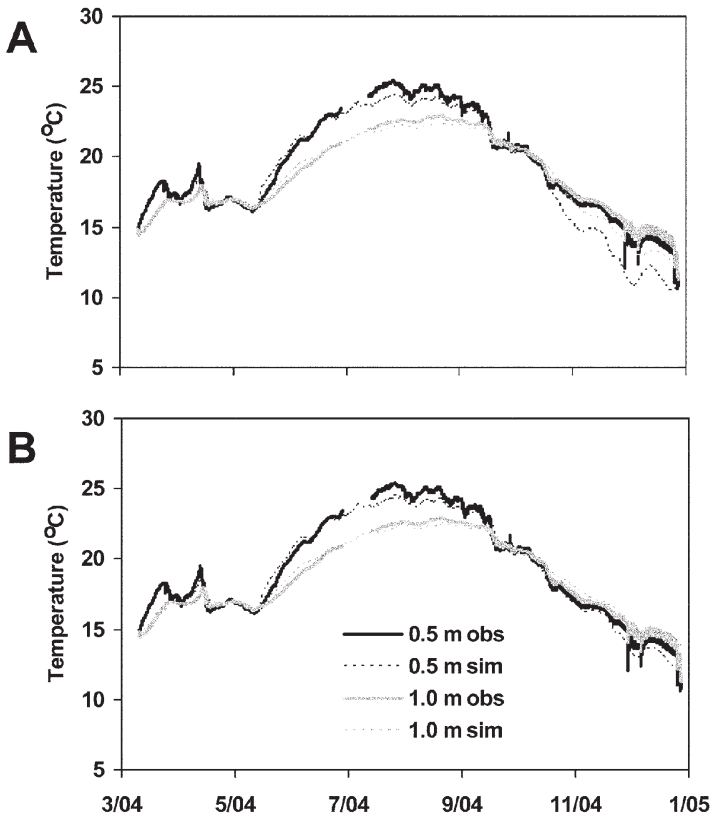

Fig. 13. Observed (obs) and simulated (sim) temperatures in the Merced River, CA, streambed for (A) a single hydraulic conductivity (K) value of $1.2 \times 10^{-5} \mathrm{~m} \mathrm{~s}^{-1}$ and $(B)$ a $\mathrm{K}$ value of 1.2 $\times 10^{-5} \mathrm{~m} \mathrm{~s}^{-1}$ for the first part of the simulation and an increased $\mathrm{K}$ value of $1.210^{-4} \mathrm{~m} \mathrm{~s}^{-1}$ after the October 2004 high-flow event.

Estimates of the velocity of water moving through the streambed can be obtained by dividing the estimated fluxes by effective porosity. Figure 14A shows the mean and range of velocity estimates for each location analyzed. The lowest streambed velocities were in the CA site (mean, $0.04 \mathrm{~m} \mathrm{~s}^{-1}$ ). Streambed velocities on the order of 0.1 to $0.3 \mathrm{~m} \mathrm{~s}^{-1}$ were observed in the WA site and the IN site with flow impeded by clay. High streambed velocities with large ranges in magnitude were observed in NE and the site in IN with no silt layer. The lowest streambed velocities were observed in the western arid basins.

The amount of time that water remains in the highly reactive streambed zone is of interest to the study of the fate of agricultural chemicals. The residence time of water in the streambed for each site expressed as the number of days per meter of travel through the streambed is shown in Fig. 14B. Assuming one-dimensional vertical flow through the sediments, this is simply the inverse of the mean velocity. At the IN and NE, sites it takes about a day for a packet of water to travel $1 \mathrm{~m}$ through the streambed, whereas at the CA site it takes an average of $24 \mathrm{~d}$. Thus, the duration of reaction with the streambed differs greatly with streambed environment.

Similarly, streambed flux and residence time vary throughout the year at each site. Figure 15 shows the estimated total upward (positive) and downward (negative) monthly flux of water at each site, expressed as cubic meters per square meter of streambed surface area. The net monthly flux is the sum of the monthly positive and negative fluxes. Monthly flows are roughly an order of magnitude larger in the humid basins (IN and $\mathrm{NE}$ ) than in the arid basins (WA and CA). Downward flux, in response to sudden high streamflows, and seasonal variability in flux are most pronounced in the humid basins. This seasonal 

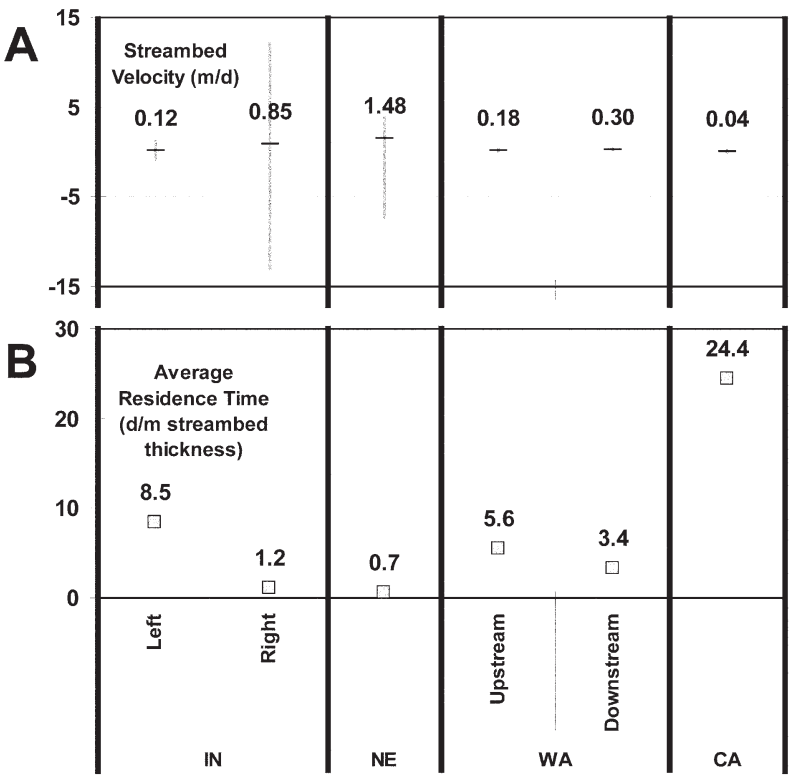

Fig. 14. Graph showing model-estimated $(A)$ mean streambed velocity (vertical gray bar represents velocity range) and (B) mean residence time of water per unit streambed thickness for the four stream reaches.

variability in flux should be considered when analyzing groundwater contributions of agricultural chemicals to stream loads.

\section{Conclusions}

Estimates of streambed water flux, in addition to streambed chemistry, are needed to calculate rates of attenuation of nitrate by streambed reactions or to calculate ground water flux contributions to nitrate loads in streams. Streambed fluxes can vary in time and space. In this study, heat was successfully used as a tracer to obtain an understanding of the temporal and spatial variability of GW/SW exchanges in the streambeds of four agricultural watersheds. Continuous measurements of temperature and heads in the streambeds demonstrated that GW/SW exchange was influenced by high flows, seasonal variations, and physical heterogeneity of the stream channel. The continuous-in-time estimates of flux obtained from the heat-flow modeling were compared with periodic measurements of flux, made using seepage meters and differential discharge measurements. Errors are associated with each of these flux estimation and measurement methods; however, in most cases (IN, NE, and CA) similar results were obtained from all methods. The temperature-based flux estimates at the WA site were significantly lower than suggested by other evidence, indicating that the piezometer nests were not located in zones of active GW/SW exchange. Thus, careful reconnaissance work should be performed before permanent installation of monitoring equipment.

Continuous estimates of flux provided insight into the nature of streambed flux between periodic measurements, long-term average fluxes, and monthly/seasonal variations in flux. Flow reversals were detected in three of the basins studied (IN, NE, and CA). Fluxes were an order of magnitude higher in the relatively humid basins (IN, NE), and seasonal variability due to climate conditions (IN, NE) and streambed conditions (CA) were observed.
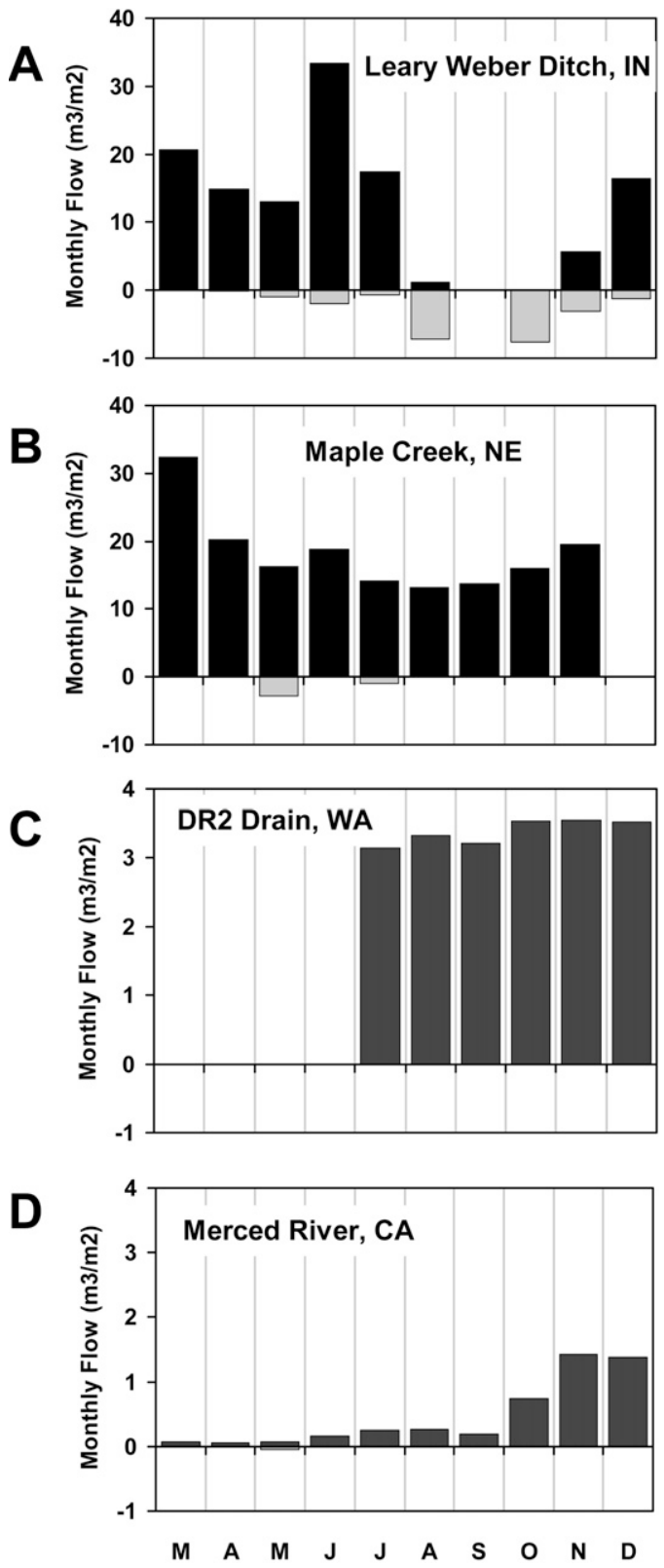

Fig. 15. Monthly flow through the streambeds of (A) Leary Weber Ditch, IN, (B) Maple Creek, NE, (C) DR2 Drain, WA, and (D) Merced River, CA. Positive values represent upward flow through the streambed. Negative values represent downward flow through the streambed (all values are expressed as cubic meters of water per unit streambed surface area). Net monthly flow is the sum of positive and negative monthly flow.

These results suggest that vertical one-dimensional models provide reasonable estimates of streambed flux. They also indicate that streambed flux is spatially variable and may be focused toward high hydraulic conductivity zones in the streambed. Flow in the ground water and streambed is multidimensional. Future efforts should explore obtaining continuous temperature and head measurements from spatially intensive monitoring networks. These data would facilitate multidimensional water and heat flow modeling to characterize the complex nature of GW/ SW interactions. These models could be combined with stream- 
bed chemistry data to investigate reactive transport of agricultural chemicals through the streambed.

\section{Acknowledgments}

This research was conducted as part of the U.S. Geological Survey, National Water-Quality Assessment Program, Agricultural Chemicals: Sources, Transport, and Fate topical study. We would like to acknowledge Dave Uuk in IN and the other landowners who made it possible for us to collect the data used in this analysis. We also thank James Constantz, Rich Niswonger, and three anonymous reviewers for their reviews and valuable comments. The use of trade names in this paper is for identification purposes only and does not constitute endorsement by the U.S. Geological Survey.

\section{References}

Anderson, M.P. 2005. Heat as a ground water tracer. Ground Water 43:951-968.

Alexander, M.D., and D. Caissie. 2003. Variability and comparison of hyporheic water temperatures and seepage fluxes in a small Atlantic salmon stream. Ground Water 41:72-82.

Bartolino, J.R., and R.G. Niswonger. 1999. Numerical simulation of vertical ground-water flux of the Rio Grande from ground-water temperature profiles, Central New Mexico. USGS Water-Resources Investigation Rep. 99-4212.

Bradley, P.M., P.B. McMahon, and F.H. Chapelle. 1995. Effects of carbon and nitrate on denitrification in bottom sediments of an effluentdominated river. Water Resour. Res. 31:1063-1068.

Capel, P.D., P.A. Hamilton, and M.L. Erwin. 2004. Studies by the U.S. Geological Survey on Sources, Transport, and Fate of Agricultural Chemicals. USGS Fact Sheet 2004-3098.

Capel, P.D., K.A. McCarthy, and J.E. Barbash. 2008. National, holistic, watershed-scale approach to understand the sources, transport, and fate of agricultural chemicals. J. Environ. Qual. 37:983-993.

Conant, B. 2004. Delineating and quantifying ground water discharge zones using streambed temperatures. Ground Water 42:243-257.

Constantz, J. 1998. Interaction between stream temperature, streamflow, and ground water exchanges in alpine stream. Water Resour. Res. 34:1609-1615.

Constantz, J., and D.A. Stonestrom. 2003. Heat as a tracer of water movement near streams. p. 1-6. In D.A. Stonestrom and J. Constantz (ed.) Heat as a tool for studying the movement of ground water near streams. USGS Circ. 1260. USGS, Washington, DC.

Craig, A.L. 2006. Evaluation of spatial and temporal variation of ground water discharge to streams. M.S. thesis. Clemson Univ., Clemson, SC.

Duff, J.H., J. Tesoriero, B. Richarson, E. Strauss, and M. Munn. 2006. Whole stream responses to nitrate loading in three streams draining agricultural landscapes in Washington, Maryland, and Nebraska. National Water Quality Monitoring Council, 5th National Monitoring Conference, 7-11 May 2006, San Jose, CA.

Duff, J.H., and F.J. Triska. 1990. Denitrification in sediments from the hyporheic zone adjacent to a small forested stream. Can. J. Fish. Aquat. Sci. 47:1140-1147.

Essaid, H.I., J.T. Wilson, and N.T. Baker. 2006. Spatial and temporal variability in streambed fluxes, Leary Weber Ditch, Indiana. Proc. of the 3rd Federal Interagency Hydrologic Modeling Conf., Joint Federal Interagency Conf., 2-6 Apr. 2006, Reno, NV.

Fredrick, B.S., J.I. Linard, and J.L. Carpenter. 2006. Environmental setting of Maple Creek watershed, Nebraska. USGS Scientific Investigations Rep. 2006-5037. USGS, Washington, DC.

Fryar, A.E., E.J. Wallin, and D.L. Brown. 2000. Spatial and temporal variability in seepage between a contaminated aquifer and tributaries to the Ohio River. Ground Water Monit. Rem. 20:129-146.

Gorman, P.D. 2004. Spatial and temporal variability of hydraulic properties in the Russian River streambed, central Sonomal County, California. M.S. thesis. San Francisco State Univ., San Francisco, CA.

Gronberg, J.M., and C.K. Kratzer. 2006. Environmental setting of the lower Merced River basin, California. USGS Scientific Investigations Rep.
2006-5152. USGS, Washington, DC.

Gray, H.H. 1989. Quaternary geologic map of Indiana. Geological Survey Miscellaneous Map 49, scale 1:500,000. Indiana Dep. of Natural Resources, Indianapolis, IN.

Healy, R.W., and A.D. Ronan. 1996. Documentation of computer program VS2DH for simulation of energy transport in variably saturated porous media-Modification of the U.S. Geological Survey's computer program VS2DT. USGS Water-Resources Investigations Rep. 96-4230. USGS, Washington, DC.

Hsieh, P.A., W. Wingle, and R.W. Healy. 2000. VS2DI: A graphical software package for simulating fluid flow and solute or energy transport in variably saturated porous media. USGS Water-Resources Investigations Rep. 99-4130. USGS, Washington, DC.

Israelson, O.W., and R.C. Reeve. 1944. Canal lining experiments in the delta area, Utah. Utah Agric. Exp. Stn. Tech. Bull. No. 313.

John, P.H., and M.A. Lock. 1977. The spatial distribution of groundwater discharge into the littoral zone of a New Zealand lake. J. Hydrol. 33:391-395.

Lathrop, T.R. 2006. Environmental setting: Natural factors and human influences affecting water quality in the Sugar Creek and Leary Weber Ditch basins, Indiana, 2002-2004. USGS Scientific Investigations Rep. 2006-5170. USGS, Washington, DC.

Lee, D.R. 1977. A device for measuring seepage flux in lakes and estuaries. Limnol. Oceanogr. 22:140-147.

Niswonger, R.G., and D.E. Prudic. 2003. Modeling heat as a tracer to estimate streambed seepage and hydraulic conductivity. p. 81-89. In D.A. Stonestrom and J. Constantz (ed.) Heat as a tool for studying the movement of ground water near streams. USGS Circ. 1260. USGS, Washington, DC.

Payne, K.L., H. Johnson, and R.W. Black. 2007. Environmental setting of the Granger Drain and DR2 Basins, Washington, 2003-2004. USGS Scientific Investigations Rep. 2007-5102. USGS, Washington, D.C.

Poeter, E.P., and M.C. Hill. 1998. Documentation of UCODE, a computer code for universal inverse modeling. USGS Water-Resources Investigations Rep. 98-4080. USGS, Washington, DC.

Puckett, L.J., and W.B. Hughes. 2005. Transport and fate of nitrate and pesticides: Hydrogeology and riparian zone processes. J. Environ. Qual. 34:2278-2292.

Puckett, L.J., C. Zamora, H.M. Johnson, J.T. Wilson, J.R. Vogel, and M.J. Brayton. 2008. Transport and fate of nitrate at the ground water-surface water interface. J. Environ. Qual. 37:1034-1050.

Ronan, A.D., D.E. Prudic, C.E. Thodal, and J. Constantz. 1998. Field study and simulation of diurnal temperature effects on infiltration and variably saturated flow beneath an ephemeral stream. Water Resour. Res. 34:2137-2152.

Rosenberry, D.O. 2005. Integrating seepage heterogeneity with the use of ganged seepage meters. Limnol. Oceanogr. Methods 3:131-142.

Rosenberry, D.O., and M.A. Menheer. 2006. A system for calibrating seepage meters used to measure flow between ground water and surface water. USGS Scientific Investigations Rep. 2006-5053. USGS, Washington, DC.

Ruehl, C., A.T. Fisher, C. Hatch, M. Los Huertos, G. Stemler, and C. Shennan. 2006. Differential gauging and tracer tests resolve seepage fluxes in a strongly-losing stream. J. Hydrol. 330:235-248.

Sebestyen, S.D., and R.L. Schneider. 2001. Dynamic temporal patterns of near shore seepage flux in a headwater Adirondack lake. J. Hydrol. 247:137-150

Silliman, S.E., and D.F. Booth. 1993. Analysis of time-series measurements of sediment temperature for identification of gaining versus losing portions of Judy Creek, Indiana. J. Hydrol. 146:131-148.

Silliman, S.E., J. Ramirez, and R.L. McCabe. 1995. Quantifying downflow through creek sediments using temperature time series: One-dimensional solution incorporating measured surface temperature. J. Hydrol. 167:99-119.

Stauffer, P.H. 2006. Flux flummoxed: A proposal for consistent usage. Ground Water 44:125-128.

Stonestrom, D.A., and K.W. Blasch. 2003. Determining temperature and thermal properties for heat-based studies of surface-water ground-water interactions. p. 73-80. In D.A. Stonestrom and J. Constantz (ed.) Heat as a tool for studying the movement of ground water near streams. USGS Circ. 1260.USGS, Washington, DC.

Tesoriero, A.J., T.B. Spruill, H.E. Mew, Jr., K.M. Farrell, and S.L. Harden. 2005. Nitrogen transport and transformations in a coastal plain watershed: Influence of geomorphology on flow paths and residence times. Water Resour. Res. 41:W02008 doi:10.1029/2003WR002953.

Zamora, C. 2006. Estimating rates of exchange across the sediment/water interface in the lower Merced River, CA. M.S. thesis. California State Univ., Sacramento. 